\title{
Development of Science Teaching Materials Based on Ecological Value of Mangrove Ecosystems as a Strategy to Improve Science Literacy of Junior High School Students on the South Coast of East Lombok
}

\author{
Didik Santoso ${ }^{1,2 *}$, Abdul Syukur1,2, Lalu Zulkifli 1,2, Zulhalifah ${ }^{1}$ \\ ${ }^{1}$ Department of Sciences Education Postgraduate Mataram University Indonesia \\ ${ }^{2}$ Department of Biological Sciences Education, Faculty of Teacher Training and Education, Mataram University, Indonesia
}

\section{DOI: $10.29303 /$ ippipa.v8i1.1325}

\section{Article Info}

Received: December 15, 2021

Revised: January 15, 2022

Accepted: January 18, 2022

Published: January 31, 2022

\begin{abstract}
Environmental characteristics in coastal areas receive less attention from educational aspects, especially schools integrating with science learning. This research aims to develop mangrove ecological value-based teaching materials as a strategy to improve students' science literacy. The research methods used are observation methods and quasi-experiments. Data analysis uses descriptive statistical analysis using, then the normality and homogeneity test is done with SPSS 17.0. Next, to test the hypothesis using ANOVA One Way. The science literacy ability of learners is measured using pre-test and post-test questionnaires. The results showed that mangrove ecological value-based teaching materials are worth using based on expert and teacher validation. The response of learners to the teaching materials developed is very interesting. The homogeneity test showed the significance of students' science literacy abilities obtained Levene test scores $>0.05$ which means the data is homogeneous. Based on the hypothesis test $\mathrm{H}_{0}$ was rejected, which means there is a significant increase in student science literacy after using teaching materials based on the ecological value of mangrove ecosystems. The effectiveness of teaching materials is evidenced by the percentage of changes in learners' average pre-test and post-test results. The highest post-test grade post-test score was $80.35 \%$, and the lowest was $79.44 \%$. The conclusion is that mangrove ecological value-based teaching materials are significant to students' science literacy skills, especially in the coastal areas of East Lombok. Therefore, it is necessary to utilize the location's potential as a source of learning learners to be more attractive.
\end{abstract}

Keywords: Teaching materials; Mangrove ecology; Science literacy

Citation: Santoso, D., Syukur, A., Zulkifli , L. \& Zulhalifah, Z. (2022). Development of Science Teaching Materials Based on Ecological Value of Mangrove Ecosystems as a Strategy to Improve Science Literacy of Junior High School Students on the South Coast of East Lombok. Jurnal Penelitian Pendidikan IPA, 8(1), 283-290. https://doi.org/10.29303/jppipa.v8i1.1325

\section{Introduction}

Innovation in the learning process, especially for high literacy aspects, is the purpose of science learning and has a strategic role in improving learners' quality through direct interaction with learning objects, such as the surrounding environment (Purwono, 2014; Rahayu, 2012). Nevertheless, the facts show that students' science literacy skills in 2018, especially in Indonesia, were in the 70 th post of 78 particscienceting countries. Furthermore, for almost 20 years, Indonesia has always been at the bottom, related to science literation, where Indonesia is under OECD member countries (Setiadi, 2014). Related to the low literation of students, especially in Indonesia, the causative factor is the 
limited choice of teaching materials as a source of learning (Wen, et al., 2020).

Science literacy is a necessity that becomes a goal as an indicator of students' level of competence. In this case, the scientific competence of students can produce innovative products from learning outcomes that have been done. The concept of science literacy covers three dimensions, and among them is (1) an understanding of the norms and methods of science, (2) an understanding of key scientific terms and concepts, and (3) awareness and understanding of the impact of science and technology on the environment and society (Dani, et al., 2013; Cavas, et al., 2013; Fives, et al., 2014; Wen, et al., 2020). Therefore, understanding the concept of science that covers the three aspects above through education is a solution to achieve optimal educational results (Ristanto, et al., 2017). Therefore, learning innovations, especially from material sources, have a very important meaning, especially those sourced from the environment.

The environment as a source of learning, such as mangrove ecosystems, has relevant ecological potential as teaching materials under the science curriculum of 2013. Topics of science learning that have relevance to the ecological potential of mangrove ecosystems as science teaching materials are the classification of living things, temperature and energy, living system organization, ecosystems, environmental pollution, and climate change. In this case, schools in coastal areas have a wealth of natural ecosystems, such as mangrove ecosystems, seagrass meadows, and estuarins. Meanwhile, the coastal environment at the study site has natural potential in mangrove ecosystems that can be grouped into three zones. Those coastal environments are the northern zone, which includes Tanjung Luar, Pijot, and Ketapang Raya, the central zone includes Jor Bay and its surroundings, and the southern zone includes Ekas Bay. Mangroves on the south coast of East Lombok have an area of 201.75 ha and have 10 species of mangroves. The 6 abiotic mangrove environments that have been identified are substrate, soil $\mathrm{pH}$, water $\mathrm{pH}$, dissolved oxygen, salinity (Idrus, et al., 2019a). The ecological potential of mangrove ecosystems at the study site is the diversity of fauna which includes the gastropod class consisting of 11 families, molluscs consisting of 11 families, Bivalvia consisting of 4 families, Malacostraca which includes 2 families and Reptilia which includes 2 families (Idrus, et al., 2019b).

The ecological potential of the mangrove ecosystem above is a representative learning object to enhance the scientific cauldron of students. However, optimizing learning resources, such as the mangrove ecosystem environment, requires design as a guide to understand and interpret it. One of them is the design of interesting teaching materials for teachers and students of SPM, especially in the study site. In this case, where environmental materials are integrated into teaching materials, learners can achieve more than those who do not use environmentally sourced teaching materials (Effiong and Igiri, 2015). In addition, teaching materials sourced from the student environment can make it easier for them to understand and interpret learning goals (Aji, et al., 2018). Furthermore, science learning materials that are quite relevant to the potential of mangrove ecosystems are ecosystem materials, an adaptation of living things to their environment, and the identification of plant parts (Saputri, et al. 2019). Meanwhile, learning sourced from the surrounding environment can foster learners' soft skills towards conservation, such as caring about the environment, love of the environment, responsibility, creative and objectivity (Savitri, et al., 2016). In addition, learning that integrates environmental situations is a form of learning innovation that cares about the environment. Innovation models in environmentally sourced learning approaches are part of a strategy involving their experience to construct their problem-solving abilities (Mahanal, et al., 2019).

The development of ecologically-based teaching materials for mangrove ecosystems is a need for conservation through formal education. In addition, the school needs teaching materials that have a cauldron of scientific information sourced from the environment. Meanwhile, the demand to achieve high science literation is still a problem for schools and teachers. Therefore, research on the development of science teaching materials based on the ecological value of mangrove ecosystems needs to be done as a strategy to raise taken science literation of students at junior high schools on the southern coast of East Lombok.

\section{Method}

This research was conducted in July-September 2021, the research site at SMPN 2 Keruak and MTSS Nurul Ihsan NW Tanjung Luar Keruak Subdistrict, East Lombok Regency. The type of research used is all experiments (Quasi Experiment). The research design used is the Nonequivalent Pretest-Posttest Control Group Design. The population in this study is a purposive sampling technique. Research samples were treated in experimental and conventional groups in control classes (El Islami, et al., 2019). The development of learners' teaching materials through several stages consists of the validation of expert assessment, validation of materials, and assessment of teacher practicality (Wardani and Anggraeni, 2020). Data collection is done using questionnaires and tests. Furthermore, data análysis is performed by descriptive statistical análysis and homogeneity test using SPSS 
17.0. Then the hipótesis test is done using ANOVA OneWay.

\section{Results and Discussions}

\section{Test of the feasibility of teaching materials}

Teaching materials are validated by four experts consisting of two expert lecturers and two SCIENCE teachers. Validation data consists of four aspects of assessment: language, characteristics, material content, and presentation. According to expert lecturers and teachers, validation data is presented in table 1 and table 2. Table 1 shows that all four aspects have a score on the category very well. The assessment of aspects of language consists of an assessment of the arrangement of words, terms, and symbols in teaching materials. Then the characteristic aspect consists of an ecological assessment of mangrove ecosystems integrated into teaching materials. The material's content consists of question items, including teaching material. Furthermore, the presentation aspect consists of assessing layout and graphics on teaching materials.

Table 1. Expert Validation Assessment

\begin{tabular}{llll}
\hline No. & Score Aspects & Score & Category \\
\hline 1 & Language & 3.50 & Very Good \\
2 & Characteristic & 4.00 & Very Good \\
3 & Material Content & 3.50 & Very Good \\
4 & Serving & 3.00 & Good \\
Average & 3.60 & Very Good \\
\hline
\end{tabular}

The development of teaching materials sourced from the ecology of mangrove ecosystems received a good response from SCIENCE teachers. SCIENCE teachers argue that this teaching material is very suitable for schools located in coastal areas. Learners can observe directly in the environment and add insight and literacy skills (Burt, et al., 2019; Falloon, 2019; Wardani and Anggraeni, 2020). Based on the teacher validation assessment, all four aspects have a very good score on the category (Table 2).

Tabel 2. Teacher Validation Assessment

\begin{tabular}{llll}
\hline No. & Score Aspects & Score & Category \\
\hline 1 & Language & 4.00 & Very Good \\
2 & Characteristic & 3.50 & Very Good \\
3 & Material Content & 3.50 & Very Good \\
4 & Serving & 3.50 & Very Good \\
Average & 3.60 & Very Good \\
\hline
\end{tabular}

Data on learners' response to the teaching materials of the Problem Based Learning model based on the ecological value of mangrove ecosystems compiled by researchers fall into an interesting category. Data on the student response questionnaire results are presented in Table 3. Table 3 shows that the three aspects of assessment of the categories are quiet, interesting, and very interesting. Overall, the teaching materials of the Problem Based Learning model based on the ecological value of mangrove ecosystems are declared suitable for use. It is because learners assess the teaching materials of the Problem Based Learning model based on the ecological value of mangrove ecosystems that are quite interesting and very interesting. Aspects of the language get a very interesting and interesting response with percentages of $43.38 \%$ and $54.67 \%$, and for sufficient response of $4.60 \%$.

Tabel 3. Student Response

\begin{tabular}{lllll}
\hline \multicolumn{2}{l}{ Percentage of Learners (\%) } & & \\
Aspects & Less & Enough & Interesting & $\begin{array}{l}\text { Very } \\
\text { Interesting }\end{array}$ \\
\hline $\begin{array}{l}\text { Language } \\
\text { Material }\end{array}$ & 0 & 4.89 & 43.38 & 54.67 \\
$\begin{array}{l}\text { Content } \\
\text { Serving }\end{array}$ & 0 & 4.51 & 35.66 & 55.32 \\
$\begin{array}{l}\text { Rat-average } \\
(\%)\end{array}$ & 0 & 8.89 & 37.56 & 57.68 \\
\hline
\end{tabular}

Aspects of material content get three responses: quite, interesting, and very interesting, with consecutive percentages of $4.51 \%, 35.66 \%$, and $55.32 \%$. Similarly, the presentation aspect gets three quite, interesting, and very interesting responses, with percentages of $8.89 \%, 37.56 \%$, and $57.68 \%$. The average response value is very interesting at $55.89 \%$. Local potential-based education provides knowledge, skills, and behavior to students to have a broad insight into the state of the surrounding environment (Tinja, et al., 2017). In addition, optimizing the region's potential will have a positive impact on learners (Winayarti, 2015). SCIENCE learning is one part of learning that has great potential in utilizing the environment as a source of learning.

The student's assessment of the display of ecosystem teaching materials in the form of material offering sequences makes students understand the intent that the teaching material wants to convey. The page view is very interesting, with a color composition that suits the environment. Student response to mangrove ecology-based teaching materials with a very interesting category because teaching materials present materials sourced from the environment around the residence.

\section{Characteristics of the development of teaching materials}

1. Teaching materials based on the ecological value of mangrove ecosystems

Teaching materials developed are integrated with mangrove ecology to have the newness of teaching materials in general. The utilization of mangrove ecology as a source of learning learners is one way that learning can attract learners' attention. The cover 
display on the teaching material highlights the mangrove image so that learners will be curious about its contents (Figure 1.a). One of the teaching materials is the flow of energy in mangrove ecology. This material will discuss the food chain and food webs. The flow of energy in mangrove ecology is very different from that in terrestrial and marine ecosystems. It is what distinguishes it from teaching materials in general. The main advantages of this teaching material are based on research from environmental objects studied before. In addition, mangrove ecology-based teaching materials are still few that develop it. The development of Student Worksheet based on the study of mangrove ecosystems has been developed by several researchers (Febri, et al., 2019; Lorena, et al., 2019).

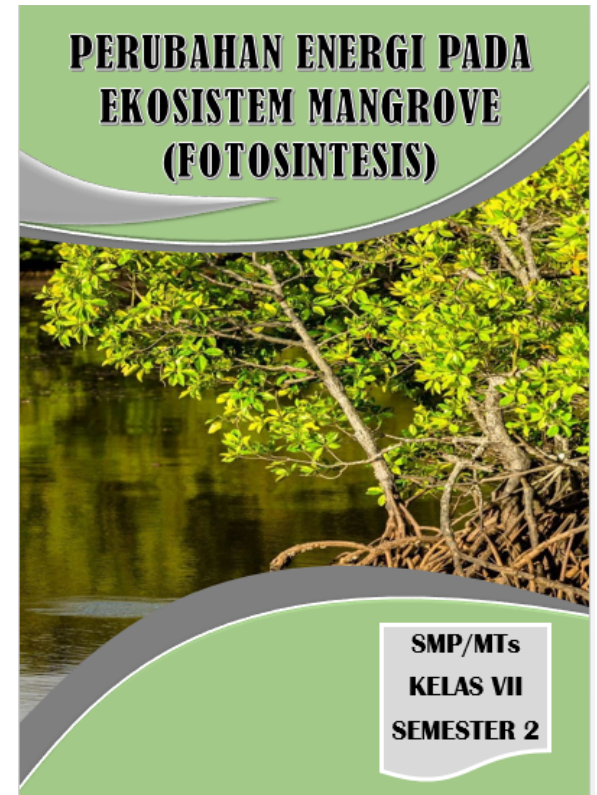

a.

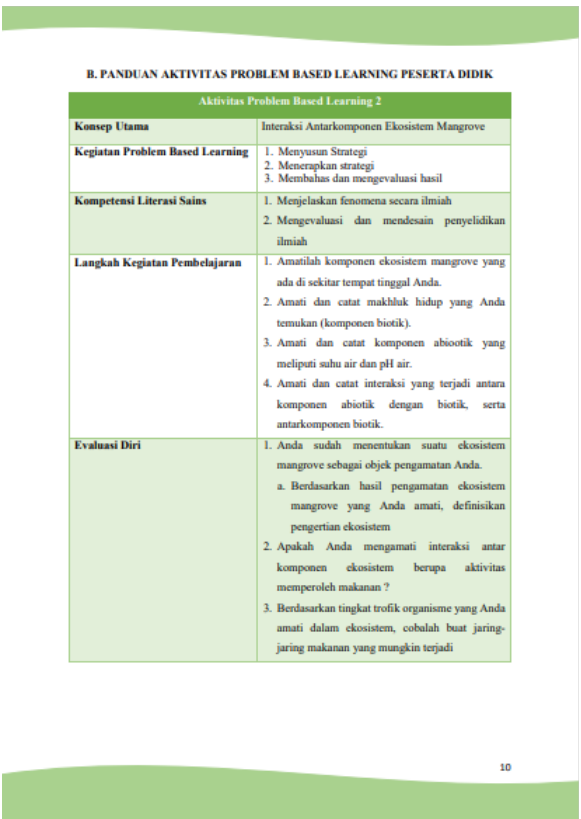

d.

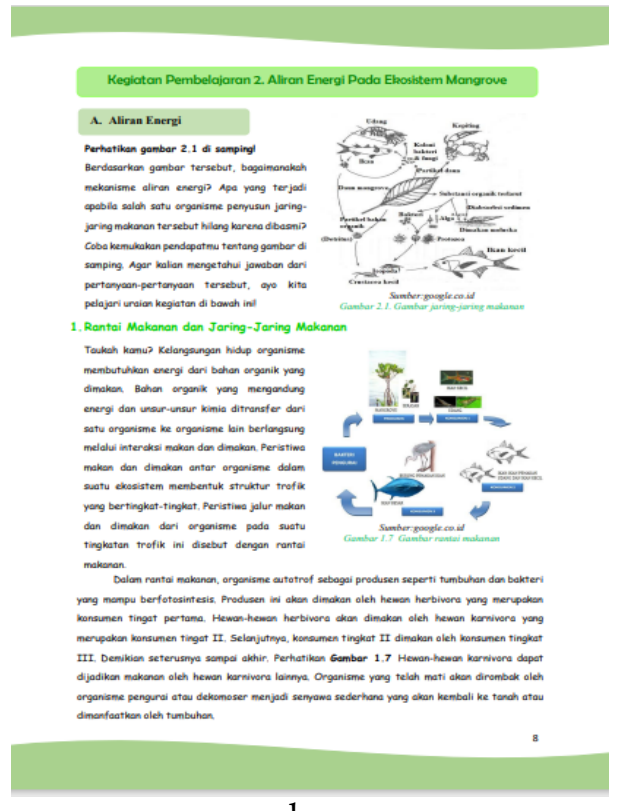

b.

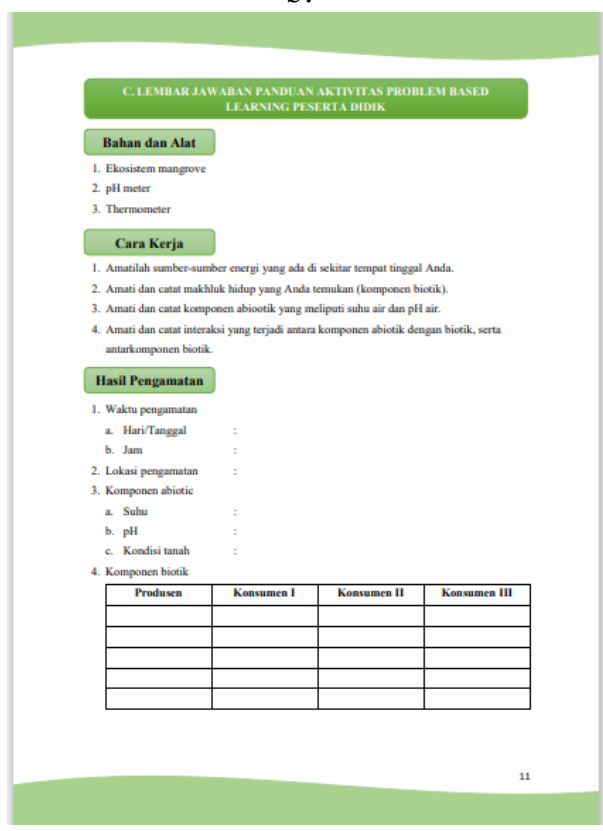

e.

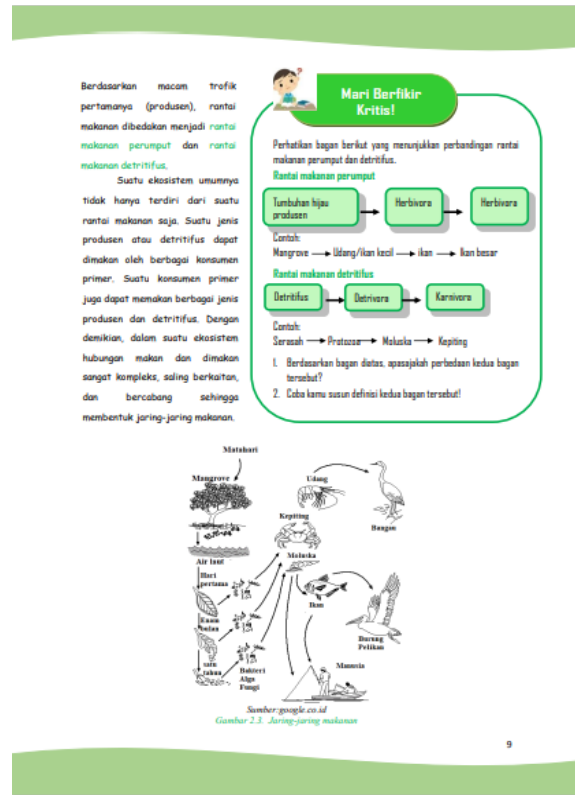

c.

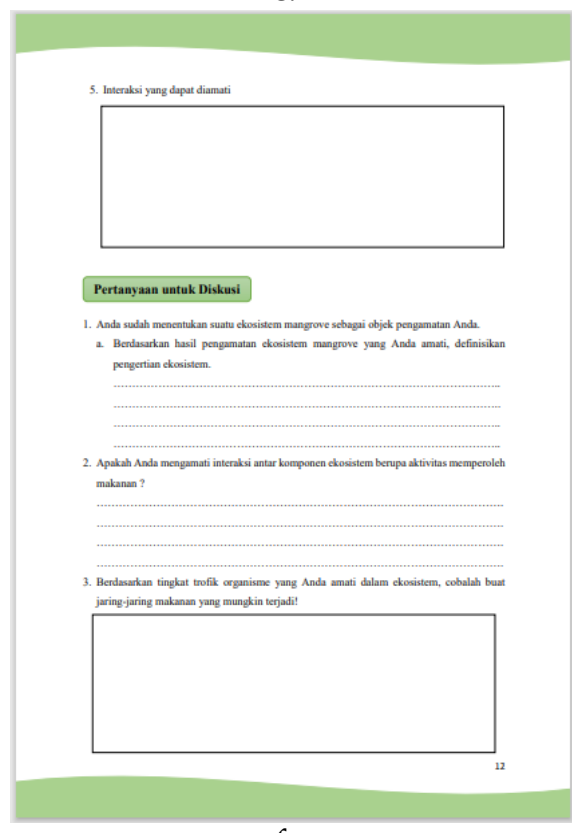

f.

Figure 1. a. Display of the cover of teaching materials; b and c. Display of material on teaching materials; d. View of the student's Problem Based Learning activity guide; e and f. View of the answer sheet of the learner's Problem Based Learning activity guide

2. Problem Based Learning model teaching materials

This development research produces a product in the form of materials in the form of problem-based learning models on basic competencies 3.2 "analyze energy concepts, various energy sources, and changes in energy forms in Everyday life including photosynthesis. The development of this teaching material is carried out with the stages of the Problem 
Based Learning model. Teaching materials are developed based on the problem in the real world so that learners are expected to be more active and able to solve problems in real contexts. Problem Based Learning model is related to critical thinking skills. Problem Based Learning model emphasizes more efforts in solving problems through research activities. Information processing activities are one of the characteristics of science literacy skills. The development of teaching materials is related to the Problem Based Learning activity guide. This activity guide aims to guide learners in conducting Problem Based Learning activities during this learning process (Figure 1.d). In addition, there is an answer sheet from the Problem Based Learning activity guide used by learners to answer the questions given.

\section{Pre-test and Post-test of Science Literacy}

Teaching materials based on science literacy developed tested its effectiveness by conducting posttests. It aims to find out whether experimental classroom students' improved science literacy skills are higher than the control classes. Students' science literacy skills are measured using multiple-choice questions. It consists of indicators explaining phenomena scientifically, evaluating and designing scientific investigations, and interpreting and proving data scientifically. The question of science literacy is given before applying mangrove ecology-based teaching materials through pre-test and after using teaching materials through post-test. The results of the pre-test, post-test, and N-Gain of science literacy students on the implementation of teaching materials based on the ecological value of mangrove ecosystems are presented in Table 4 . Table 4 represents the average pre-test, and post-test results analyzed, with N-Gain being in the moderate category of control and experimental classes. There is an increase in the ability of science literacy students after the post-test. After implementing teaching materials, the increase in science literacy is in line with research conducted by Muzijah et al. (2020). It happens because teaching materials are equipped with problems that train learners' literacy skills.

Table 4. Pre-test and post-test scores for control classes and experiments

\begin{tabular}{llllll}
\hline $\begin{array}{l}\text { Name of } \\
\text { school }\end{array}$ & Class & $\begin{array}{l}\text { Pre- } \\
\text { test }\end{array}$ & $\begin{array}{l}\text { Post- } \\
\text { test }\end{array}$ & Score & Criterion \\
\hline SMPN 2 & Control & 56.67 & 71.94 & 0.30 & Keep \\
Keruak & Experiment & 66.67 & 79.44 & 0.40 & Keep \\
MTs NW & Control & 60.88 & 74.12 & 0.30 & Keep \\
Nurul & Experiment & 65.59 & 80.35 & 0.40 & Keep \\
Ihsan & & & & & \\
Tanjung & & & & & \\
Luar & & & & & \\
\hline
\end{tabular}

\section{Homogeneity Test}

The next stage is a homogeneity test to identify the variance of data is homogeneous or not. The homogeneity test was conducted using post-tests of students' science literacy skills and controls. The homogeneity test of the variant is carried out with the help of SPSS 17.0. Interpretation of data is said to be homogeneous when levene test results show p-value greater than $=5 \%$ or $0.05(\mathrm{p}$-value $\bar{\alpha}>0.05)$ in other words, and both variants are equally large (Equalvariances assumed). Conversely, if the result shown is a $\mathrm{p}$-value smaller than $=5 \%$ or $0.05 \sqrt{\alpha}$ (p-value $<0.05)$, then the data is said to be heterogeneous because the two variants are not the same. The results of the variant homogeneity test can be seen in table 5 . The results of the variant homogeneity test in table 5 showed that the significance of students' science literacy abilities obtained Levene test scores > 0.05 which means the data is homogeneous. It can be seen that in SMP 2 Keruak has a significance value of 0.269 in the control class and the experimental class of 0.446 . Further, MTs NW Nurul Ihsan Tanjung Luar has a significance value of 1,000 in the control class and the experimental class of 0.296 .

Table 5. Variant homogeneity test results

\begin{tabular}{lllll}
\hline & Levene Statistics & df1 & df2 & Significance \\
\hline K1SMP & 1.263 & 1 & 32 & 0.269 \\
E1SMP & 0.596 & 1 & 32 & 0.446 \\
K2MTS & 0.000 & 1 & 32 & 1.000 \\
E2MTS & 1.127 & 1 & 32 & 0.296 \\
\hline
\end{tabular}

\section{Hypothesis Test}

Data analysis of hypotheses test uses analysis of variance (ANOVA) to test the average difference in data over two groups. It aims to see if there is a difference between the group's given treatment or not. The ANOVA test used in this study is ANOVA One Way or one-way variant analysis. Based on the oneway ANOVA test results in table 6 it is known that the value of its significance is $0.000<0.05$, so $\mathrm{H}_{0}$ is rejected. So, it can be concluded that there is a significant increase in students' science literacy after using teaching materials based on the ecological value of mangrove ecosystems. 
Table 6. Oneway ANOVA Results

\begin{tabular}{lllllll}
\hline & & Sum of Squares & Df & Mean Square & F & Significance \\
\hline K1SMP & Between Groups & 1118.382 & 1 & 1118.382 & 42.250 & 0.000 \\
& Within Groups & 847.059 & 32 & 26.471 & & \\
& Total & 1965.441 & 33 & & & \\
E1SMP & Between Groups & 1297.059 & 1 & 1297.059 & 23.097 & 0.000 \\
& Within Groups & 1797.059 & 32 & 56.158 & & \\
& Total & 3094.118 & 33 & & 48.943 & 0.000 \\
\multirow{2}{*}{ K2MTS } & Between Groups & 1488.971 & 1 & 1488.971 & & \\
& Within Groups & 973.529 & 32 & 30.423 & & \\
\multirow{2}{*}{ E2MTS } & Total & 2462.500 & 33 & & 27.864 & 0.000 \\
& Between Groups & 1852.971 & 1 & 1852.971 & & \\
& Within Groups & 2128.000 & 32 & 66.500 & & \\
& Total & 3980.971 & 33 & & & \\
\hline
\end{tabular}

The linkage of teaching materials of the Problem Based Learning model based on the ecological value of mangrove ecosystems with increased science literacy is interconnected. It can be seen that Problem Based Learning activities are considered to improve science literacy. This learning model can train learners to do science activities themselves, both in learning in the classroom and in everyday life. In addition, the Problem Based Learning model effectively improves students' science literacy skills on four aspects: competence, knowledge, context, and attitudes (Alatas \& Fauziah, 2020). Lack of student activities to improve science literacy and problem-based learning will reduce science learning quality. Following Jufri \& Hikmawati (2014), the dismay of science will impact the development of learners' skills.

The material for teaching the Problem Based Learning model based on the ecological value of mangrove ecosystems needs to be applied to the learning process. The goal is to use problem-based learning activities to teach learners to do science literacy activities. The benefits of learners can improve their science literacy skills. Learners will have the ability to understand and solve problems faced in everyday life. In addition, the concept of science is concrete and supported by the integration of mangrove ecology in learning. Learners will find information as much as possible about the subject matter because it is close to the environment around the residence.

The use of problem-based learning model teaching materials by utilizing the environment around mangrove ecology is intended to foster students' caring attitudes to the environment and mangrove ecology. Characteristics of muddy mangrove ecology, zoning in mangrove forests, and adaptation of mangrove forests as examples of ecosystem teaching materials. This teaching material can develop the affective realm in students by associating these examples with the positive values contained in them. It follows the statement that the utilization of coastal environmental values, such as mangrove ecology, as a source of learning is one of the efforts in maintaining the coastal environment. (Sunarto, et al, 2020; Amawa, et al, 2020). Enrichment of science teaching materials sourced from the surrounding environment aims to provide positive achievement and make it easier for students to understand natural-based learning objects (Effiong \& Igiri, 2015; Aji, et al., 2018).

The science literacy skills of particsciencents must be improved in the learning process and an ongoing manner with new innovations. It will be the iteration of science (Science Literacy) is one of the areas of PISA studies (Programme for International Student Assessment) that focuses on a person's ability to use scientific knowledge and skills in making decisions and solving problems (Fives, 2014; El Islami, 2019). Science literacy is an individual's scientific knowledge and capacity to use that knowledge to identify questions, acquire new knowledge, explain scientific phenomena and draw evidence-based conclusions on issues related to science (OECD, 2014).

\section{Conclusion}

Based on the results of data analysis and discussion, it can be concluded that the development of problem-based learning model teaching materials based on the ecological value of mangrove ecosystems can improve the science literacy of learners. It can be seen from the post-test results higher than the results of pre-test learners. In addition, the $\mathrm{H}_{0}$ hypothesis test was rejected, which means there is an influence of teaching materials on improving the science literacy of learners. Mangrove ecology-based learning has the advantage of utilizing the surrounding environment as a source of learning. Therefore, the utilization of coastal values such as mangrove ecology can be considered a source of educational development. Mainly to improve 
the litigation process of student science in the southern coastal region of East Lombok.

\section{References}

Aji, G. P., Pratiwi, Y., \& Widiarti,N. (2018). Development Of Instructional Materials Writing Poetry Based on Nature Tourism for Poetry Learning. Isllac: Journal of Intensive Studies on Language, Literature, Art, and Culture, 2(1), 35-39. http://dx.doi.org/10.17977/um006v2i12018p035

Al-Idrus, A. (2014). Mangrove Gili Sulat East Lombok. Mataram: Arga Praises Press.

Alatas, F., \& Fauziah, L. (2020). Problem based learning model to improve science literacy skills in the concept of global warming. JIPVA (Journal of Veteran SCIENCE Education), 4(2), 102-113. https://doi.org/10.31331/iipva.v4i2.862

Amawa, I., Yerizon,Y., Sri, N., \& Putra, R. T. (2019). Development of students' worksheet based on apos theory approach to improve student achievment in learning system of linear equations. International Journal of Scientific and Technology Research, 8(4), 287-292. Retrieved from http://repository.unp.ac.id/26413/

Burt, J. A., Killilea, M. E., \& Ciprut, S. (2019). Coastal urbanization and environmental change: Opportunities for collaborative education across a global network university. Regional Studies in Marine Science, 26,100501. https://doi.org/10.1016/j.rsma.2019.100501

Cavas, P.H., Pınar, H., Ozdem, Y., Cavas, B., Cakiroglu, J., \& Ertepina, H. (2013). Turkish preservice elementary science teachers' scientific literacy level and attitudes toward science. Science Education International, 24(4): 383-401. Retrieved from https:/ / eric.ed.gov/?id=EJ1022326

Dani, D. (2013). Scientific literacy and purposes for teaching science: a case study of lebanese private school teachers. International Journal of Environmental \& Science Education. 4(3). 289-299.

Effiong, O.E., \& Igiri, C.E. (2015). Impact of instructional materials in teaching and learning of biology in senior secondary schools in Yakurr LG A. International letters of Social and humanistic sciences, $\quad 62, \quad 27-33$ http://dx.doi.org/10.18052/www.scipress.com/I LSHS.62.27

El Islami, R. A. Z., Sari, I. J., Sjaifuddin, S., Nurtanto, M., Ramli, M., \& Siregar,A. (2019). An Assessment of Pre-service Biology Teachers on Student Worksheets Based on Scientific Literacy. In Journal of Physics: Conference Series. 1155(1), p. 012068. http://dx.doi.org/10.1088/1742$\underline{6596 / 1155 / 1 / 012068}$
Falloon, G. (2019). Using simulations to teach young students science concepts: An Experiential Learning theoretical analysis. Computers $\mathcal{E}$ Education, 135, 138-159. https://doi.org/10.1016/j.compedu.2019.03.001

Febri, A.A., Kasrina, K., \& Idrus, I. (2019). Development of Student Worksheet Based on Mangrove Ecosystem Study in Bengkulu Long Beach Natural Park Area. Diklabio: Journal of Biological Education and Learning, 3(1), 1-7. https://doi.org/10.52237/lej.v4i2.120

Fives, H., Huebner, W., Birnbaum, A. S., \& Nicolich, M. (2014). Developing a measure of scientific literacy for middle school students. Science Education, 98(4), 549-580. https://doi.org/10.1002/sce.21115

Idrus, A. A., Syukur,A., \& Zulkifli,L. (2019b). The livelihoods of local communities: Evidence success of mangrove conservation on the coastal of East Lombok Indonesia. In AIP Conference Proceedings 2199(1), p. 050010. https://doi.org/10.1063/1.5141308

Idrus, A.A., Syukur, A., \& Zulkifli,L. (2019a). The diversity of fauna in mangrove community: Success replanting of mangroves species in South Coastal East Lombok, Indonesia. In Journal of Physics: Conference Series 1402(3), p. 033042). http:doi:10.1088/17426596/1402/3/033042

Jufri, A.W., \& Hikmawati. (2014). Analisis Kemelekan Sains (Scince Literacy) dan Kemelekan Inkuiri (Inquiry Literacy) Guru Mataa Pelajaran IPA SMP. Jurnal Pijar MIPA, 9 (1), 9-14. http://dx.doi.org/10.29303/jpm.v9i1.37

Lorena, M., Kasrina, K., \& Yani, A.P. (2019). Pengembangan LKPD Model Discovery Learning Berdasarkan Identifikasi Mangrove di TWA Pantai Panjang Bengkulu. Diklabio: Jurnal Pendidikan dan Pembelajaran Biologi, 3(1), 59-66. https://doi.org/10.33369/diklabio.3.1.59-66

Mahanal, S., Zubaidah, S., Sumiati, I.D., Sari, T.M., \& Ismirawati, N. (2019). RICOSRE: A Learning Model to Develop Critical Thinking Skills for Students with Different Academic Abilities. International Journal of Instruction, 12(2),417-434. https://eric.ed.gov/?id=EJ1211048

Muzijah, R., Wati, M., \& Mahtari, S. (2020). Pengembangan E-modul Menggunakan Aplikasi Exe-Learning untuk Melatih Literasi Sains. Jurnal Ilmiah Pendidikan Fisika, 4(2), 8998. https:// doi.org/10.20527/jipf.v4i2.2056

OECD. (2014). PISA 2012 Results in Focus What 15-YearOlds Know and What They Can Do with What They Know. Paris:PISA OECD Publishing. Retrieved from

https:// www.oecd.org/pisa/keyfindings/pisa2012-results-overview.pdf 
Purwono, J. (2014). Penggunaan media audio-visual pada mata pelajaran ilmu pengetahuan alam di Sekolah Menengah Pertama Negeri 1 Pacitan. Jurnal teknologi pendidikan dan pembelajaran, 2(2), 142050. Retrieved from http://jurnal.fkip.uns.ac.id/index.php/tp/article $\angle$ view/3659

Rahayu, P,S. Mulyani, S.S., \& Miswadi. (2012). Pengembangan Pembelajaran IPA Terpadu dengan Menggunakan Model Pembelajaran Problem Base Melalui Lesson Study. Jurnal Pendidikan IPA Indonesia, 1(1), 63-70. https://doi.org/10.15294/jpii.v1i1.2015

Ristanto, R. H., Zubaidah,S., Amin, M., \& Rohman,F. (2017). Scientific literacy of students learned through guided inquiry. International Journal of Research and Review, 4(5), 23-30. Retrieved from https://www.ijrrjournal.com/IJRR_Vol.4_Issue.5 May2017/Abstract_IJRR004.html

Saputri, D. N., Winarni, E. W., \& Gunawan, A. (2019). Pengaruh Pemanfaatan Hutan Mangrove sebagai Sumber Belajar IPA terhadap Sikap Peduli Lingkungan Siswa Kelas IV SD Kota Bengkulu. Jurnal PGSD: Jurnal Ilmiah Pendidikan Guru Sekolah Dasar. $\quad 12(2): \quad 150-$ 158. https://doi.org/10.33369/pgsd.12.2.150-158

Savitri, E.N., \& Sudarmin, S. (2016). Penerapan pendekatan jas (jelajah alam sekitar) pada mata kuliah konservasi dan kearifan lokal untuk menanamkan softskill konservasi pada mahasiswa ipa unnes. Unnes Science Education Journal, 5(1): 102-107. https://doi.org/10.15294/usej.v5i1.9570

Setiadi, D. (2014). Model Pembelajaran Berbasis Peningkatan Literasi Sains dan Implementasinya dalam Kurikulum Sains SMP 2013. Jurnal Pijar Mipa, $9(1)$. http://dx.doi.org/10.29303/jpm.v9i1.36

Sunarto, S., Prasetiya, F. S., \& Bachtiar, E. (2020). Sosialisasi Pemanfaatan Senyawa Bioaktif Dari Mikroalga Diatom Dalam Praktik Budidaya Perikanan Berkelanjutan Di Kabupaten Indramayu. Dharmakarya, 9(2), 117-120. https://doi.org/10.24198/dharmakarya.v9i2.238 $\underline{58}$

Tinja, Y., Towaf, S. M., \& Hariyono, H. (2017). Pengembangan bahan ajar tematik berbasis kearifan lokal sebagai upaya melestarikan nilai budaya pada siswa sekolah dasar. Jurnal Pendidikan: Teori, Penelitian, Dan Pengembangan, 2(9), $1257-1261$ https://doi.org/10.17977/jptpp.v2i9.9990

Wardani, S., \& Anggraeni, A. Y. 2020. The effectiveness of guided inquiry learning based on contextual to improve chemistry literacy ability of senior high school students. In Journal of Physics:
Conference Series. 1567(2), p. 022041). https://doi.org/10.1088/1742-

6596/1567/2/022041

Wen, C. T., Liu, C.C., Chang, H. Y., Chang, C. J., Chang, M. H., Chiang, S. H. F., \& Hwang, F. K. (2020). Students' guided inquiry with simulation and its relation to school science achievement and scientific literacy. Computers \& Education, 149, 103830.

https://doi.org/10.1016/j.compedu.2020.103830

Winayarti, E. (2015). Development Model Pembelajaran "Wisata Lokasl" Kabupaten Rembang, Jawa Tengah. Sains Jurnal Pendidikan. 3(1), 34-42. https://doi.org/10.26714/jps.3.1.2015.34-42 